\title{
Sisal Organosolv Pulp as Reinforcement for Cement Based Composites
}

\author{
Ana Paula Joaquima, Gustavo Henrique Denzin Tonoli ${ }^{\text {b }}$ \\ Sérgio Francisco Dos Santos ${ }^{\text {a }}$ Holmer Savastano Junior ${ }^{\text {a* }}$ \\ ${ }^{a}$ Faculdade de Zootecnia e Engenharia de Alimentos, \\ Universidade de São Paulo - USP, \\ Av. Duque de Caxias Norte, 225, 13635-900 Pirassununga - SP, Brazil \\ ${ }^{\mathrm{b}}$ Escola de Engenharia de São Carlos, Universidade de São Paulo - USP \\ Av. Trabalhador São-Carlense, 400, 13566-590 São Carlos - SP, Brazil
}

Received: December 5, 2008; Revised: May 17, 2009

\begin{abstract}
The present work describes non-conventional sisal (Agave sisalana) chemical (organosolv) pulp from residues of cordage as reinforcement to cement based materials. Sisal organosolv pulp was produced in a 1:1 ethanol/water mixture and post chemically and physically characterized in order to compare its properties with sisal kraft pulp. Cement based composites reinforced with organosolv or kraft pulps and combined with polypropylene (PP) fibres were produced by the slurry de-watering and pressing method as a crude simulation of the Hatschek process. Composites were evaluated at 28 days of age, after exposition to accelerated carbonation and after 100 soak/dry cycles. Composites containing organosolv pulp presented lower mechanical strength, water absorption and apparent porosity than composites reinforced with kraft pulp. The best mechanical performance after ageing was also achieved by samples reinforced with kraft pulp. The addition of PP fibres favoured the maintenance of toughness after ageing. Accelerated carbonation promoted the densification of the composites reinforced with sisal organosolv + PP fibres.
\end{abstract}

Keywords: fibres, fibre/matrix bond, mechanical properties, physical properties

\section{Introduction}

In several developed countries, cellulose fibres are used as reinforcement of cement-based materials and in order to provide an alternative for low cost buildings by adaptation of the former asbestos-cement production process ${ }^{1}$.

Tropical countries present significant opportunities for the production of non-wood lignocellulosic fibres ${ }^{2}$, especially if they are available from by-products of the main commercial agricultural activities (e.g., cordage). With the low cost of raw materials and simplified pulping methods, the resulting cellulose pulp has considerable potential for fibre-cement production at significantly lower costs than those associated with the use of conventional kraft wood pulps ${ }^{3}$.

Alkaline kraft pulping is the dominant chemical pulping process today, but it presents some serious shortcomings, as air and water pollution and the high investment costs. These shortcomings have led to the development of several organosolv methods capable of producing pulp with properties near those of kraft pulp ${ }^{4}$.

Diverse solvents, pure or in mixtures, can be used to promote delignification ${ }^{5-7}$. Amongst them, the process that involves ethanol is the most used, regarding the recovery facilities, the better impregnation of vegetal tissue by solvent, the easier recovery of lignin and polysaccharides from the pulping liqueur beyond the efficient delignification and favourable conditions of operation in alcohol producer's countries ${ }^{8-10}$.

The lignin dissolution in the organosolv processes is a result of hydrolysis of ether bonds, as $\alpha-\mathrm{O}-4$ and $\beta-\mathrm{O}-4$ bonds of lignin macromolecules ${ }^{11}$. Organosolv delignification also consists in the breaking of ether bonds between carbohydrates and carbon atoms from the lateral chains of lignin ${ }^{12}$. According to Aziz and Goyal ${ }^{13}$ cleavage of alpha-ether linkages is the most important reaction in the lignin molecule breakdown during organosolv pulping. The bulk delignification in ethanol:water pulping is a phenomenon involving breakdown of the lignin with high molecular weight and solubilisation of its breakdown products ${ }^{14}$. Ethanol acts as a scavenger for the free radicals formed during pulping and reduces the extent of lignin condensation. Some side chain rearrangement and ethoxylation of benzyl alcohol groups occurs. This reaction prevents the lignin molecule from recondensing during the pulping process ${ }^{15}$.

In the kraft process the lignin extraction from cell wall occurs at the initial stage of delignification, whereas the lignin from middle lamella is extracted at the final stage of delignification. In the organosolv processes, the lignin extraction occurs first at the middle lamella and lignin from cell wall is poster dissolved ${ }^{16,17}$. This characteristic of the organosolv pulp must be of great interest since it decreases the tendency of fibre interlayer debonding during the soak/dry cycling of the fibre-cement composites, and consequently prevents the reprecipitation of hydration products within the fibre cell wall, minimizing fibre mineralization ${ }^{18}$

This work reports on the investigation of an alternative chemical (organosolv) pulping process applied to residues of sisal (Agave sisalana) strand fibres from industry of cordage. The organosolv pulp is used as reinforcement of cement based composites in comparison to commercial sisal pulp obtained by the conventional kraft pulping process. 


\section{Experimental}

\subsection{Materials}

Sisal (Agave sisalana) field by-product was provided by Associação de Desenvolvimento Sustentável e Solidário da Região Sisaleira (Apaeb), Brazil. Sisal strand fibres originated from residues of the cordage industry, with the following physical and mechanical characteristics: around $5 \mathrm{~mm}$ long and approximately $0.2 \mathrm{~mm}$ average diameter, around $360 \mathrm{MPa}$ tensile strength ${ }^{19}, 15.0 \mathrm{GPa}$ elastic modulus ${ }^{20}$ and $5 \%$ strain at failure ${ }^{19}$. The raw material was first chemically characterized and then pulped under organosolv process.
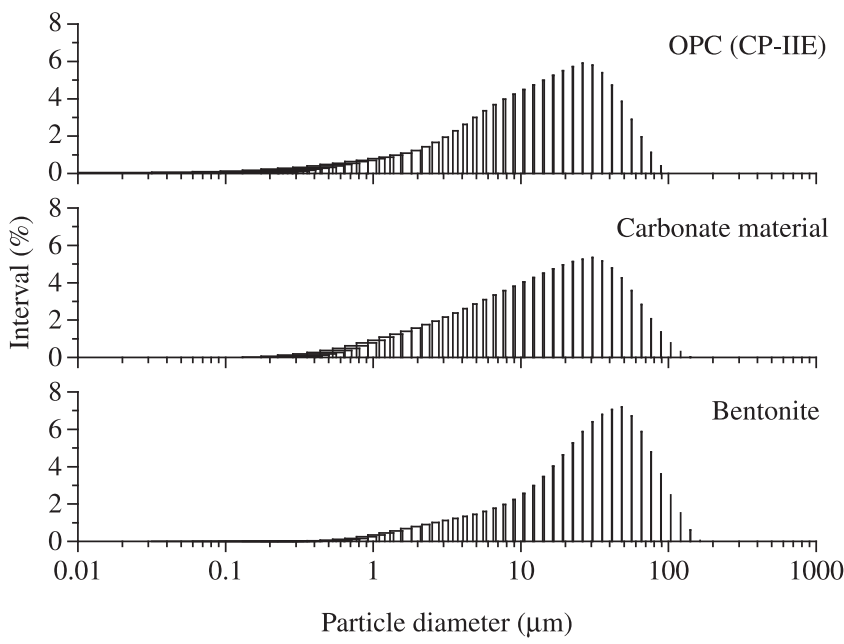

Figure 1. Particle size distribution of OPC (CP-IIE), carbonate material and bentonite.
Conventional sisal kraft pulp with up to $3 \%$ total Klason lignin was provided by Lwarcel Celulose e Papel, Brazil. The unrefined pulp with fibres concentration of $5.3 \mathrm{~g} / \mathrm{L}$ in water was submitted to a stirring process in water and was post-refined by several passes through the $300 \mathrm{~mm}$ diameter disc refiner ( $3 \mathrm{~mm}$ width bar, $3 \mathrm{~mm}$ width groove and $7.5^{\circ}$ angle bar configuration) until the achievement of CSF $220 \mathrm{~mL}$ refinement degree. It was used for the refinement a specific edge load (SEL) of approximately $0.3 \mathrm{~W} . \mathrm{s} / \mathrm{m}$, operating at current intensity of $50 \mathrm{~A}$. The Canadian Standard Freeness test (CSF) is a widely recognized standard measure of the drainage properties of pulp suspensions ${ }^{21}$. Low freeness values (less than $300 \mathrm{~mL}$ ) are indicative of high degree of external fibrillation and/or shortage of the fibres, leading to long drainage periods during the test. The refinement greatly improves the manufacturing processes of fibre-cement based on slurry dewatering techniques followed by pressing 22 .

Polypropylene (PP) fibres measuring $6 \mathrm{~mm}$ long and around $0.3 \mathrm{~mm}$ width, with $300 \mathrm{MPa}$ tensile strength, $3.3 \mathrm{GPa}$ elastic modulus and $25 \%$ strain at failure (data furnished by Fitesa ${ }^{\circledR}$ S.A., Brazil), was used for the mix-design with hybrid reinforcement.

Physical and chemical properties of ordinary Portland cement (OPC) and carbonate filler are summarized in Tables 1 and 2 respectively. Carbonate filler was used for partial substitution of OPC in order to reduce costs concerning the production of fibre-cement. Bentonite (specific surface area $=0.2152 \mathrm{~m}^{2} / \mathrm{g}$ ) was used to improve the water retention. Particle size distribution was evaluated by Mastersizer S long bed 2.19 version in a Malvern equipment and was depicted in Figure 1.

According to Figure 1, 50\% of the particles are smaller than 13.59, 14.49 and $28.23 \mu \mathrm{m}$ for OPC, carbonate filler and bentonite respectively. Most of particles (90\%) are smaller than 41.75, 50.08 and $71.92 \mu \mathrm{m}$ for OPC, carbonate filler and bentonite respectively.

Table 1. Physical, chemical and mechanical characterization of ordinary Portland cement (CP-IIE $)$.

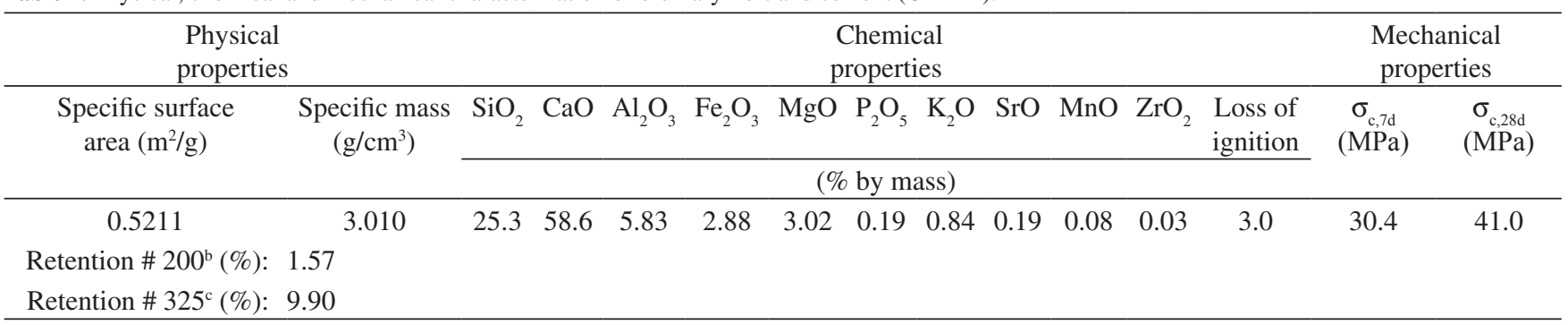

a Data provided by the supplier. Brazilian Standards NBR 11578 ${ }^{[23]}$ (1991): blast furnace slag =6-34\%; carbonate filler = 0-10\%; ${ }^{2} 200 \mathrm{mesh}$ sieve (\# 0.074 $\mathrm{mm}$ ); and ${ }^{\mathrm{C}} 325$ mesh sieve (\# $0.045 \mathrm{~mm}$ ).

Table 2. Physical and chemical characteristics of the carbonate filler.

\begin{tabular}{|c|c|c|c|c|c|c|c|c|c|c|c|c|}
\hline \multicolumn{2}{|c|}{ Physical properties } & \multicolumn{11}{|c|}{ Chemical properties } \\
\hline \multirow[t]{2}{*}{$\begin{array}{l}\text { Specific surface } \\
\text { area }\left(\mathrm{m}^{2} / \mathrm{g}\right)\end{array}$} & \multirow[t]{2}{*}{$\begin{array}{c}\text { Specific mass } \\
\left(\mathrm{g} / \mathrm{cm}^{3}\right)\end{array}$} & $\mathrm{SiO}_{2}$ & $\mathrm{CaO}$ & $\mathrm{Al}_{2} \mathrm{O}_{3}$ & $\mathrm{Fe}_{2} \mathrm{O}_{3}$ & $\mathrm{MgO}$ & $\mathrm{P}_{2} \mathrm{O}_{5}$ & $\mathrm{~K}_{2} \mathrm{O}$ & $\mathrm{SrO}$ & $\mathrm{MnO}$ & $\mathrm{TiO}_{2}$ & $\begin{array}{l}\text { Loss of } \\
\text { ignition }\end{array}$ \\
\hline & & \multicolumn{11}{|c|}{ (\% by mass) } \\
\hline 0.4298 & 2.650 & 2.47 & 44.6 & 0.45 & 0.37 & 8.56 & 0.08 & 0.17 & 0.05 & 0.06 & 0.04 & 43.3 \\
\hline Present phases (DR & \multicolumn{12}{|c|}{$\mathrm{CaCO}_{3}, \mathrm{CaMg}\left(\mathrm{CO}_{3}\right)_{2}, \mathrm{Fe}_{2} \mathrm{O}_{3}, \mathrm{SiO}_{2},(\mathrm{~K}, \mathrm{Na})(\mathrm{Al}, \mathrm{Mg}, \mathrm{Fe})_{2}\left(\mathrm{Si}_{3.1} \mathrm{Al}_{0.9}\right) \mathrm{O}_{10}(\mathrm{OH})_{2}$} \\
\hline
\end{tabular}

Source: Laboratory of Technological Characterization, Escola Politécnica, Universidade de São Paulo, Brazil. 


\subsection{Fibre characterization}

\subsubsection{Determination of insoluble and soluble Klason lignin}

- Insoluble lignin - The content of insoluble Klason lignin was determined according to Tappi Test Method ${ }^{24}$. Dry fibres $(1 \mathrm{~g})$ were solubilised with $15 \mathrm{~mL}$ of $\mathrm{H}_{2} \mathrm{SO}_{4} 72 \%$ under magnetic agitation during 2 hours. After this, the mixture was placed in a $1 \mathrm{~L}$ glass balloon added to $560 \mathrm{~mL}$ of distilled water under reflux. The mass of fibres left after filtration was dried at $100{ }^{\circ} \mathrm{C}$ until the constant mass was attained.

Reflux was performed during 2, 3, 4 and 5 hours for the sisal strand fibres in order to determine the maximum hydrolyses. The optimal time of reflux with sulphuric acid for sisal strand fibres was 4 hours and it was used also for organolsolv pulp. The content of Klason lignin was defined by Equation 1:

$$
\% R_{1}=\frac{m_{1}}{m_{m}} \times 100
$$

where $m_{m}$ is the dry mass of fibres $(\mathrm{g}), m_{l}$ is the mass of dry Klason lignin $(\mathrm{g})$ and $\% R_{l}$ is the content of insoluble Klason lignin (\%).

- Soluble lignin - The filtered solution after insoluble determination was diluted to $1 \mathrm{~L}$ with distilled water for Ultra Violet (UV) spectroscopy analyses in order to determine the soluble lignin, following the procedures described by Goldschimid ${ }^{25}$. It was prepared a reference solution from $1.5 \mathrm{~mL} 72 \%$ sulphuric acid in $100 \mathrm{~mL}$ of water. An aliquot was collected for the absorbance analyses at 280 and $215 \mathrm{~nm}$. The amount of lignin $(\mathrm{g} / \mathrm{L})$ in the diluted samples was calculated using Equation 2:

$$
C(g / L)=\frac{4.53 \times A_{215} \quad A_{280}}{300}
$$

where $C(\mathrm{~g} / \mathrm{L})$ is the content of soluble Klason lignin $(\mathrm{g} / \mathrm{L}), A_{215}$ is the absorbance at $215 \mathrm{~nm}$ and $A_{280}$ is the absorbance at $280 \mathrm{~nm}$.

\subsubsection{Determination of holocellulose content}

Holocellulose content was determined by the use of sodium chlorite in acid solution, and it is designated chlorite holocellulose. The procedure is described in the literature ${ }^{26}$. The amount of $1 \mathrm{~g}$ of fibres was diluted in $60 \mathrm{~mL}$ of distilled water under magnetic agitation at $70 \pm 2{ }^{\circ} \mathrm{C}$ during 0.5 hours. After thermal equilibrium $1.5 \mathrm{~g}$ of sodium chlorite and $2 \mathrm{~mL}$ of acetic acid were added. This procedure was repeated after 1 and 2 hours, resulting in a 3 hours reaction. Finally, the resultant mass was filtered and dried at $100{ }^{\circ} \mathrm{C}$ until constant mass. The content of holocellulose was calculated according to Equation 3:

$$
\% R_{\text {holo }}=\frac{m_{\text {holo }}}{m_{m}} \times 100
$$

where $m_{\mathrm{m}}$ is the dry mass of fibres ( $\left.\mathrm{g}\right), m_{\text {holo }}$ is the dry mass of holocellulose $(\mathrm{g})$ and $\% R_{\text {holo }}$ is the content of holocellulose $(\%)$.

\subsubsection{Determination of cellulose and polyose}

The filtered solution after the determination of insoluble Klason lignin was used for the determination of carbohydrates by high performance liquid chromatography (HPLC). The sample to be analyzed was prepared as cited by Pasquini et al. ${ }^{27}$. The amounts of cellobiose, glucose, arabinose, formic acid, acetic acid, hydroxymethylfurfural and furfural were determined. Determinations of cellobiose, glucose, xylose, arabinose and acetic acid, were performed in a Shimadzu ${ }^{\circledR}$, model CR 7A chromatograph equipped with Infrared Shimadzu R10-6A detector, column Aminex HPX 87H
(300 mm $\times 7.8 \mathrm{~mm}$, Biorad), using $\mathrm{H}_{2} \mathrm{SO}_{4}, 0.005 \mathrm{~mol} . \mathrm{L}^{-1}$ as eluent and a flow rate of $0.6 \mathrm{~mL} / \mathrm{min}$. For the determinations of furfural and hydromethylfurfural, the same chromatograph was employed with a Shimadzu Ultraviolet detector (254 nm), model SPD-10A, column RP 18 (C18) Hewlett-Packard, using acetonitrile/water $1: 8(\mathrm{v} / \mathrm{v})$ with $1 \%$ acetic acid $(\mathrm{v} / \mathrm{v})$ as eluent and flow rate equals to $0.8 \mathrm{~mL} / \mathrm{min}$.

\subsection{Organosolv pulping}

In order to observe the higher yield of the process, organosolv pulping was conducted by three periods of reactions,. In theses different experiments, pulping times were respectively 1,2 and 3 hours of reaction from the moment in which the reactor temperature reached $190{ }^{\circ} \mathrm{C}$.

The quantity of $25 \mathrm{~g}$ of by-product sisal (around $5 \mathrm{~mm}$ long) was added in a blend of ethanol and water in the range of $1: 1 \mathrm{v} / \mathrm{v}$ in a locked $1 \mathrm{~L}$ reactor. Temperature was then raised up to $190{ }^{\circ} \mathrm{C}$. After each cooking time (1, 2 and 3 hours), the reactor was cooled during 20 minutes and the pulp was filtered in a Buchner funnel. Pulp was triple washed with ethanol and dried at $100{ }^{\circ} \mathrm{C}$. The yielding was calculated according to Equation. 4:

$$
\% R_{0}=\frac{m_{0}}{m_{m}} \times 100
$$

where $m_{m}$ is the dry mass of the by-product sisal $(\mathrm{g}), m_{o}$ is the dry mass of the pulp $(\mathrm{g})$ and $\% R_{o}$ is the pulp yield (\%).

\subsubsection{Physical characterization of fibres and pulps}

The main physical attributes of the organosolv and kraft pulps were characterized by the particle size analyser Galai CIS-100. The analysis with Galai CIS-100 consists in the evaluation of the physical attributes of the whole fibrous material present in the pulp. Average length and width, coarseness, number of fibres per gram and fines content were analysed and stored with the aid of the Wshape v.1.0 software.

\subsection{Composite preparation}

Cement based composites were reinforced with sisal unrefined organosolv or refined kraft pulp and polypropylene fibres. The cement based composites were moulded in plates measuring $200 \times 200 \mathrm{~mm}$. They were prepared in laboratory scale using a slurry vacuum dewatering followed by pressing technique described in details by Savastano Jr. et al. ${ }^{22}$.

Formulations in Table 3 were established based on prior studies published elsewhere ${ }^{28,29}$. They refer to the dry mass of the solid raw materials before mixing with water.

Bentonite was previously dispersed separately in water during 10 min and post added jointly with the pulp, which was dispersed in water by mechanical stirring at $1,700 \mathrm{rpm}$ during 1 hour. The mixture formed with approximately $20 \%$ of solids was stirred at $1,700 \mathrm{rpm}$ for 20 minutes. The slurry was transferred to the evacuable casting box and the vacuum was applied ( $~ 80 \mathrm{kPa}$ gauge) until a solid surface formed. Three pads of each formulation were pressed simultaneously at $3.2 \mathrm{MPa}$ for 5 minutes. The final water/cement ratio reached after this operation was around 0.3. Pads were then sealed wet in a plastic bag to cure at room temperature for two days and immersed in water during 26 days. Pads were cut wet into four $165 \mathrm{~mm} \times 40 \mathrm{~mm}$ flexural test specimens using a diamond saw cooled with water. Specimen thickness was approximately $6 \mathrm{~mm}$. On completion of the cure, specimens were tested under saturated condition at 28 days after production. 
Table 3. Mix-design of the fibre-cement composites.

\begin{tabular}{|c|c|c|c|c|}
\hline \multirow[t]{2}{*}{ Raw material } & $\mathrm{SO}$ & SO-PP & SK & SK-PP \\
\hline & \multicolumn{4}{|c|}{$\mathrm{w} / \mathrm{w}(\%)$} \\
\hline Sisal pulp ( $\mathrm{SO}=$ unrefined organosolv, $\mathrm{SK}=$ refined kraft) & $4.7^{\mathrm{a}}$ & $3.0^{\mathrm{b}}$ & 4.7 & 3.0 \\
\hline Polypropylene fibres (PP) & - & $1.7^{\mathrm{c}}$ & - & 1.7 \\
\hline Ordinary Portland cement (CP-IIE) & 77.8 & 77.8 & 77.8 & 77.8 \\
\hline Carbonate filler & 16.5 & 16.5 & 16.5 & 16.5 \\
\hline Bentonite & 1.0 & 1.0 & 1.0 & 1.0 \\
\hline
\end{tabular}

${ }^{\mathrm{a}}$ Equivalent volume fraction $=\sim 5.0 \%$; ${ }^{\mathrm{b}}$ Equivalent volume fraction $=\sim 3.1 \%$; and ${ }^{\mathrm{c}}$ Equivalent volume fraction $=\sim 2.6 \%$.

Table 4. Sisal pulp and fibre physical properties ${ }^{\mathrm{a}}$.

\begin{tabular}{lcccccc}
\hline \multicolumn{1}{c}{ Pulp (Sisal) } & $\begin{array}{c}\text { Average } \\
\text { length }(\mathrm{mm})\end{array}$ & $\begin{array}{c}\text { Average } \\
\text { width }(\mu \mathrm{m})\end{array}$ & $\begin{array}{c}\text { Aspect } \\
\text { ratio }\end{array}$ & $\begin{array}{c}\text { Coarseness } \\
(\mathrm{mg} / 100 \mathrm{~m})\end{array}$ & $\begin{array}{c}\text { Fibrous material } \\
\left(10^{6} \text { fibres/g) }\right.\end{array}$ & $\begin{array}{c}\text { Fines } \\
\text { content }(\%)\end{array}$ \\
\hline Organosolv (unrefined) & $1.10 \pm 0.04$ & $26.4 \pm 0.2$ & 42 & $11.5 \pm 1.7$ & $8.1 \pm 1.6$ & $25.8 \pm 2.2$ \\
Kraft (unrefined) & $1.66 \pm 0.02$ & $22.2 \pm 0.5$ & 75 & $12.8 \pm 0.1$ & $4.7 \pm 0.1$ & $27.2 \pm 1.2$ \\
Kraft (CFS 220 mL) & $1.13 \pm 0.05$ & $18.7 \pm 0.2$ & 60 & $10.0 \pm 0.6$ & $8.9 \pm 0.9$ & $40.6 \pm 1.3$ \\
\hline
\end{tabular}

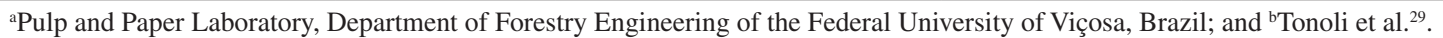

\subsection{Accelerated carbonation}

Accelerated carbonation of the composites was carried out in a climatic chamber with carbon dioxide $\left(\mathrm{CO}_{2}\right)$ saturated environment and with controlled temperature and humidity $\left(30^{\circ} \mathrm{C}\right.$ and $80 \%$ RH respectively). The composites were submitted to the climatic chamber environment during two weeks until the complete carbonation of the samples. The carbonation degree was evaluated by the exposure to a solution with $2 \%$ of phenolphthalein diluted in anhydrous ethanol as described by Agopyan et al. ${ }^{30}$.

\subsection{Soak/dry accelerated ageing cycles}

The soak/dry accelerated ageing cycles involved comparative analysis of the physical and mechanical performance of the composites before and after this test. Specimens were successively immersed in water at $20 \pm 5{ }^{\circ} \mathrm{C}$ during 170 minutes, followed by the interval of 10 minutes, and then exposed to the temperature of $70 \pm 5{ }^{\circ} \mathrm{C}$ for 170 minutes in a ventilated oven and with the final interval of 10 minutes. This procedure was based on recommendations of the EN $494^{[31]}$ Standards. Each soak/dry set represents one cycle and was performed for 100 times (i.e., 100 cycles).

\subsection{Physical and mechanical characterization}

Water absorption (WA), bulk density (BD) and apparent void volume (AVV) values were obtained from the average of ten specimens for each design, following procedures specified by the ASTM C 948-81 ${ }^{[32]}$ Standards.

Mechanical tests were performed in a universal testing machine Emic DL-30,000 equipped with $1 \mathrm{kN}$ load cell. A four-point bending configuration was employed for the determination of the values of modulus of rupture (MOR), limit of proportionality (LOP), and toughness. A span of $135 \mathrm{~mm}$ and a deflection rate of $1.5 \mathrm{~mm} / \mathrm{min}$ were adopted in the bending test. Equation 5 defines MOR:

$$
M O R=\frac{P \cdot L_{v}}{b \cdot h^{2}}
$$

where $P$ is the maximum load, $L_{v}$ is the major span between the supports, $b$ and $h$ are the specimen width and depth respectively.

The limit of proportionality (LOP) was described as the stress corresponding to the upper point of the linear portion of the stressstrain curve.
Toughness (Equation 6) was defined as the energy absorbed during the flexural test and divided by the specimen cross-sectional area. The absorbed energy was calculated by integration of the area below the load-deflection curve.

$$
\text { Toughness }=\frac{\text { absorbedenergy }}{b \times h}
$$

where $b$ and $h$ are the specimen width and depth respectively.

Scanning electron microscopy (SEM) was applied for the characterization of fibre-matrix interface on a fractured surface of specimens undergone to mechanical tests, similar to the procedures used in Savastano Jr. et al. ${ }^{33}$. Samples were gold coated in a Bal-Tec MED 020 coating system before being analysed in a Zeiss ${ }^{\circledR}$ LEO 440 microscope.

\section{Results and Discussion}

\subsection{Characterization of the sisal strand fibres}

Sisal strand fibers were characterized. Lignin content was determined after reflux with sulphuric acid as described above. Cellulose and polyose contents were determined by HPLC. The content of lignin, polyose and cellulose was $16 \pm 1,20 \pm 1$ and $65 \pm 2$, respectively. The values obtained for cellulose and polyoses are in accordance with the literature ${ }^{34}$.

\subsection{Characterization of the organosolv pulps}

It can be observed in Figure 2 that the yield for 1 hour pulping was the higher. It is attributed to the low removal of lignin, resulting in a higher mass of dry pulp. This fact indicates that 1 hour was not enough to get a satisfactory removal of lignin. Results obtained for the yield, holocellulose and lignin contents after 2 and 3 hous (Figure 2) indicated no significant variations in these properties. The period of 2 hours of pulping was sufficient to extract the maximum lignin possible of the by-product sisal. This fact would represent an economy of energy by the adoption of 2 hours of reaction instead of 3 hours.

The physical characterization of the fibrous material, i.e., entire plus damaged fibres performed in Galai equipment gives a precise idea of the actual morphology of the pulp. Results follow in Table 4.

In a previous study, Tonoli et al..$^{29}$ evaluated commercial sisal kraft pulp at different intensities of refinement (CSF 680, 220 and $20 \mathrm{~mL}$ ). The physical properties of the unrefined kraft pulp (CSF $680 \mathrm{~mL}$ ) are 


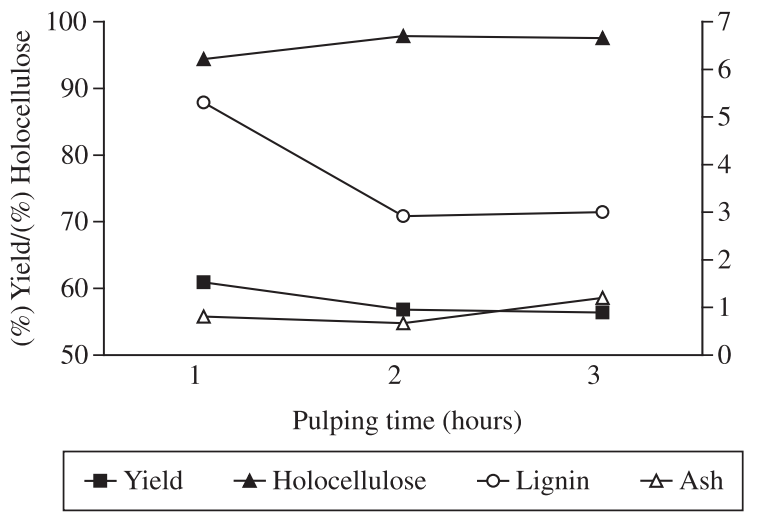

Figure 2. Results of chemical characterization of organosolv pulps at different pulping times.

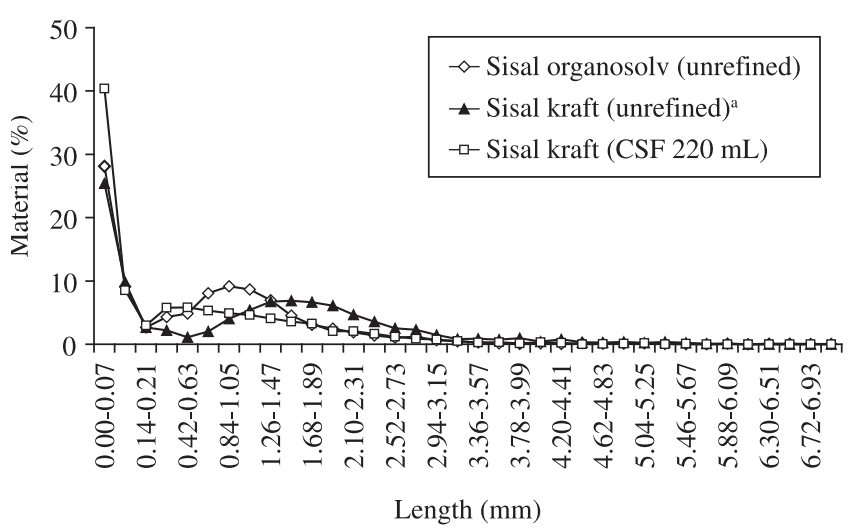

Figure 3. Length distribution of the fibrous material. ( ${ }^{(a)}$ Tonoli et al. ${ }^{29}$.

presented in Table 4. Comparison with the properties of the unrefined organosolv pulp shows similar amount of fines. The definition of fines is related to the fibres with less than $75 \mu \mathrm{m}$ of length ${ }^{35}$. The average length of organosolv pulp was lower and average width was higher in the present work, which gives a considerably lower aspect ratio. Besides, the coarseness of the organosolv pulp was lower and the amount of fibrous material per gram was higher than unrefined kraft pulp. The sisal source from residues of the cordage production should be taken in consideration in the evaluation of these data.

The refinement of the kraft pulp (CSF $220 \mathrm{~mL}$ ), as well as the organosolv pulping, has promoted an increase of the values of fibrous material per gram and diminished the length, aspect ratio, and coarseness of the pulp. Kraft pulp CSF 220 was chosen as reinforcement by the similar behaviour to the organosolv pulp, regarding the properties cited above. In this way, comparisons could be made.

The distributions of length and width for the fibrous material (obtained with the particle size analyser) can be visualized in Figures 3 and 4 respectively. According to Figure 3, most of the filaments are lower than $1 \mathrm{~mm}$ (around 65\% to sisal organosolv and sisal kraf refined, and around $47 \%$ to sisal kraft unrefined). Organosolv pulping generates shorter fibrous material than unrefined kraft pulp ${ }^{29}$. The length distribution of the organosolv pulp was similar to the refined kraft pulp (CSF $220 \mathrm{~mL}$ ). For the width distribution (Figure 4) most of the fibres (around 90\%) lie in the 5-40 $\mu \mathrm{m}$ region for the three samples. However, about $50 \%$ of the number of filaments of the sisal kraft fibres (CSF $220 \mathrm{~mL}$ ) presents width lower than $15 \mu \mathrm{m}$. In the case of sisal organosolv fibres, this amount is around $25 \%$, what indicates the more intensive external fibrillation and the ribbon like format for the refined kraft fibres.

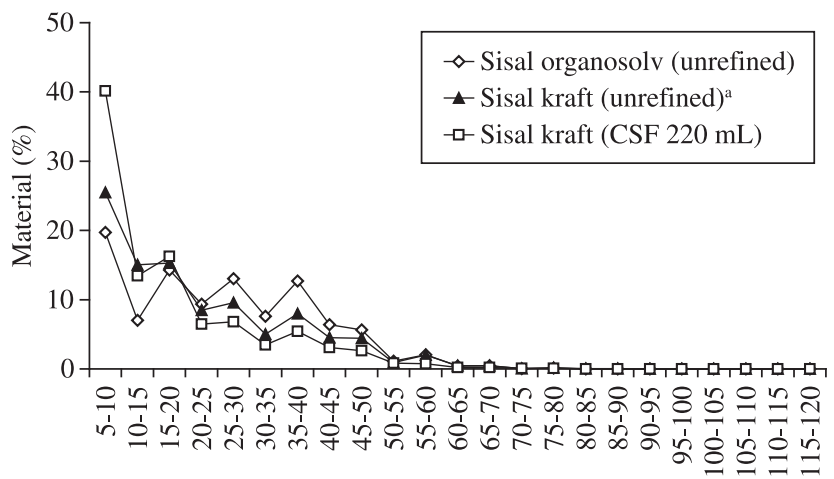

Width (mm)

Figure 4. Width distribution of the fibrous material. ( $\left.{ }^{a}\right)$ Tonoli et al. ${ }^{29}$.

\subsection{Physical results of the composites}

According to the results shown in Figure 5, at 28 days and after 100 cycles (not submitted to fast carbonation), composites with only organosolv pulp presented lower water absorption and apparent void volume than composites only reinforced with sisal kraft. Bulk density of the composites was weakly influenced (no statistical significance) by the pulping and/or refining processes of vegetable fibre.

Water absorption and apparent void volume have decreased significantly for composites fast carbonated and aged. Water absorption of the unaged composites with sisal organosolv + PP fibres was less influenced by 100 ageing cycles.

Bulk density increased significantly with the accelerated carbonation for both composites reinforced with only organosolv or kraft sisal and with sisal + PP fibres. Results for bulk density were not significantly different for composites at 28 days when compared to those after 100 ageing cycles.

Composites with sisal organosolv pulp and PP fibres as reinforcement presented higher water absorption after 100 ageing cycles over composites only reinforced with sisal organosolv pulp. This behaviour can be attributed to deficient distribution of long and hydrophobic synthetic fibres in the matrix, which can contribute to higher void content after ageing, as a probable consequence of capillaries associated to the poorer packing. In the case of the composites with refined sisal kraft the homogeneity in distribution of PP fibres was improved with the consequent low variation of the WA and AVV before and after the exposition to ageing cycles. Another fact that could contribute to lower values of water absorption in the sisal aged composites is the probable formation of hydration products around and into the cores of the cellulose fibres after the ageing cycles. Composites with only sisal kraft presented higher water absorption than those with only sisal organosolv at 28 days and after the 100 ageing cycles. A possible explanation is that aqueous ethanol penetrates easily into the structure of the fibre resulting in uniform delignification ${ }^{36}$ and besides decrease the recondensation of lignin on surface of the fibres ${ }^{15}$ by the rearrangement and ethoxylation of benzyl alcohol groups. Lower content of lignin on the fibre surface permits improved fibre-matrix bonding, decreasing porosity and water absorption of the composite.

The higher bulk density of the formulations containing only sisal pulps in comparison with composites with polypropylene fibres is partially related with the substitution of the fraction of the matrix (density $\sim 2.6 \mathrm{~g} / \mathrm{cm}^{3}$ ) and cellulose fibres (density $\sim 1.5 \mathrm{~g} / \mathrm{cm}^{3}$ ) by polypropylene fibres (density $\sim 0.9 \mathrm{~g} / \mathrm{cm}^{3}$ ). Additionally, another reason to the lower bulk density of the composites with PP fibres is the difficulty of packing the particles into the composite when using PP fibres, since these fibres are longer, less flexible/malleable, hydrophobic, and reasonably with 


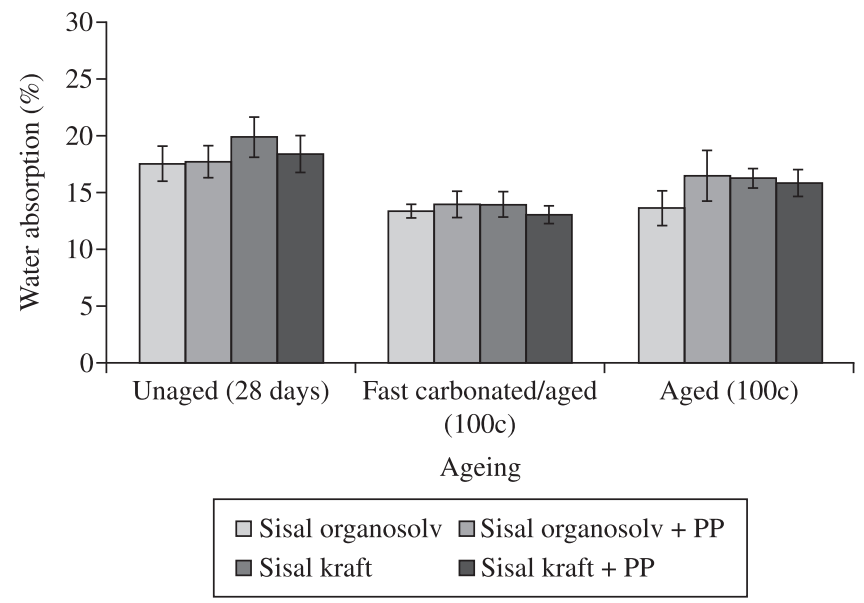

(a)

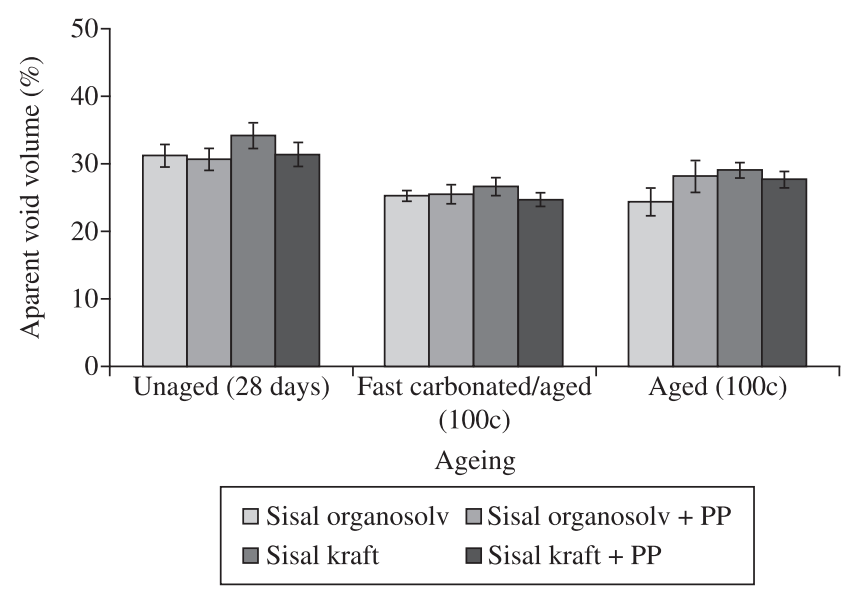

(b)

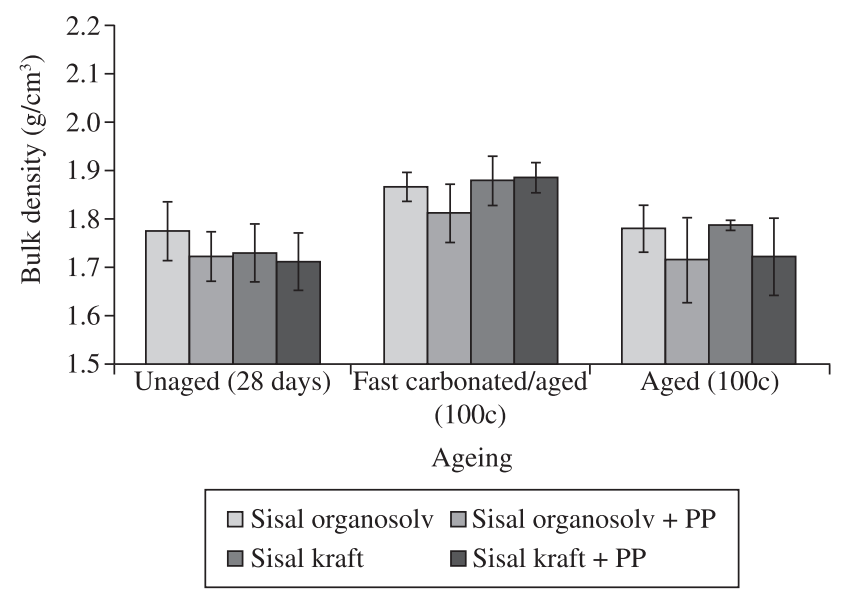

(c)

Figure 5. Physical properties of the composites reinforced with sisal organosolv and PP fibres at 28 days, fast carbonated/aged and aged. a) Water absorption, b) apparent void volume and c) bulk density.

the same size, while the sisal fibres are smaller and with a great variety of length and width (Figures 3 and 4), that can also give contribution for the improvement of composite packing.

\subsection{Mechanical results of the composites}

Figure 6 presents the results of mechanical properties of the composites before and after the ageing for both series subjected or not to fast

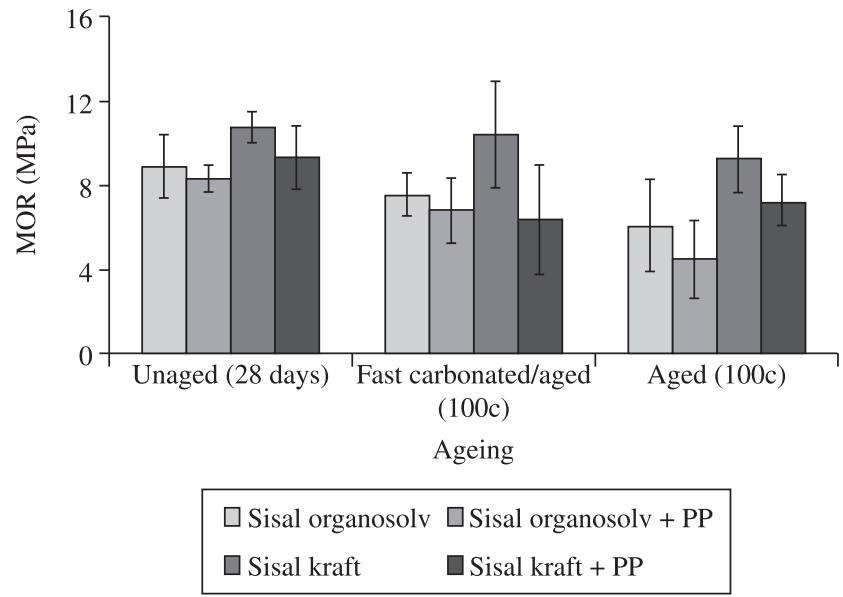

(a)

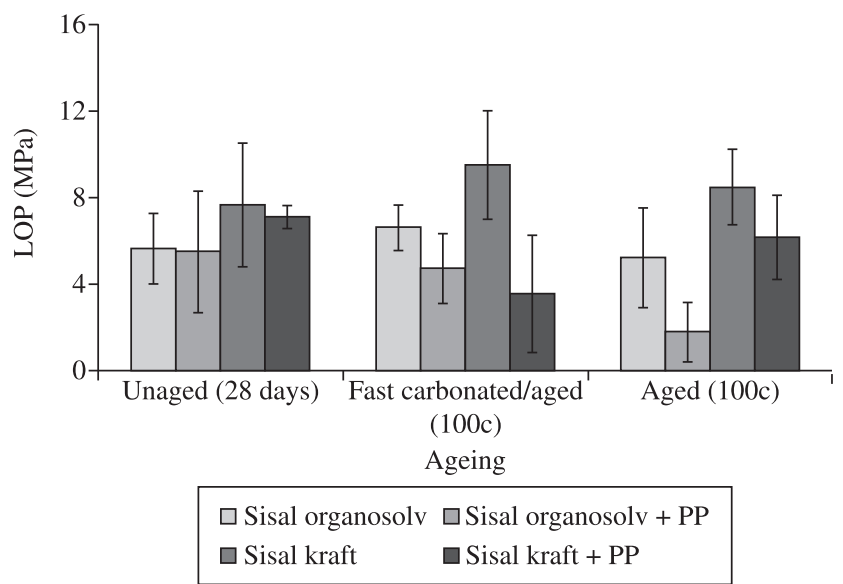

(b)

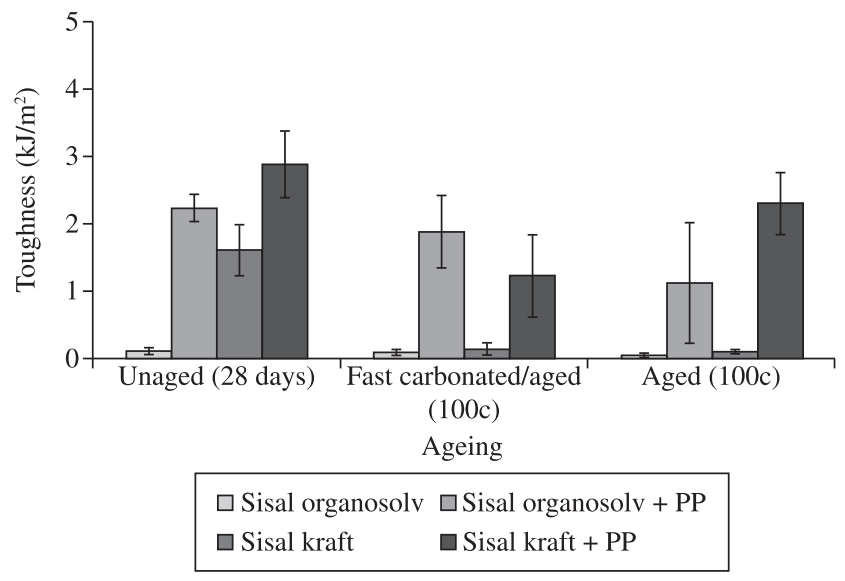

(c)

Figure 6. Mechanical properties of the composites reinforced with sisal organosolv and PP fibres at 28 days, fast carbonated/aged and aged. a) MOR, b) LOP and c) toughness.

carbonation. Composites reinforced with kraft pulp present higher MOR and LOP than the corresponding ones with organosolv pulp. Accelerated carbonation was more effective to the maintenance of MOR for the composites only reinforced with sisal kraft than composites reinforced with only organosolv pulp. Fast carbonated/aged composites presented higher MOR, LOP and toughness than those only aged (without fast carbonation) reinforced with organosolv pulp + PP fibres. 


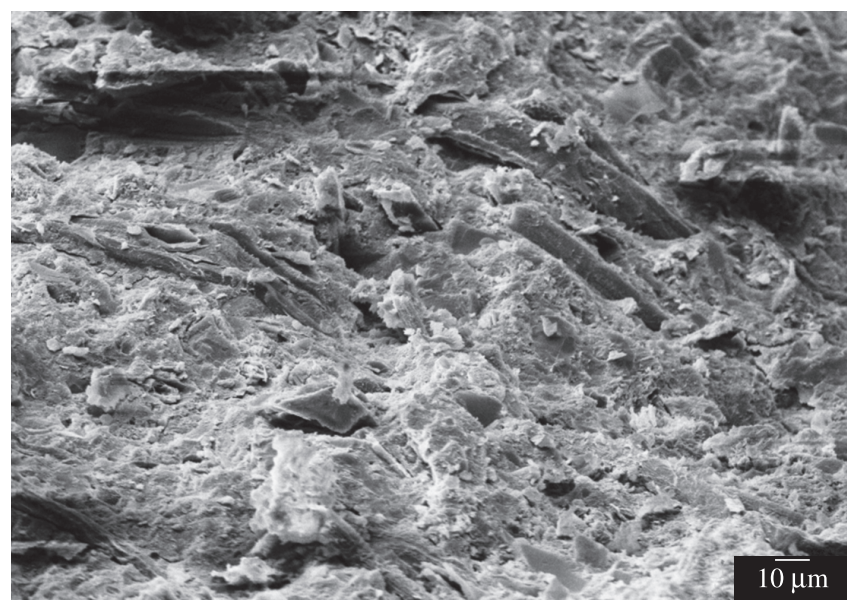

(a)

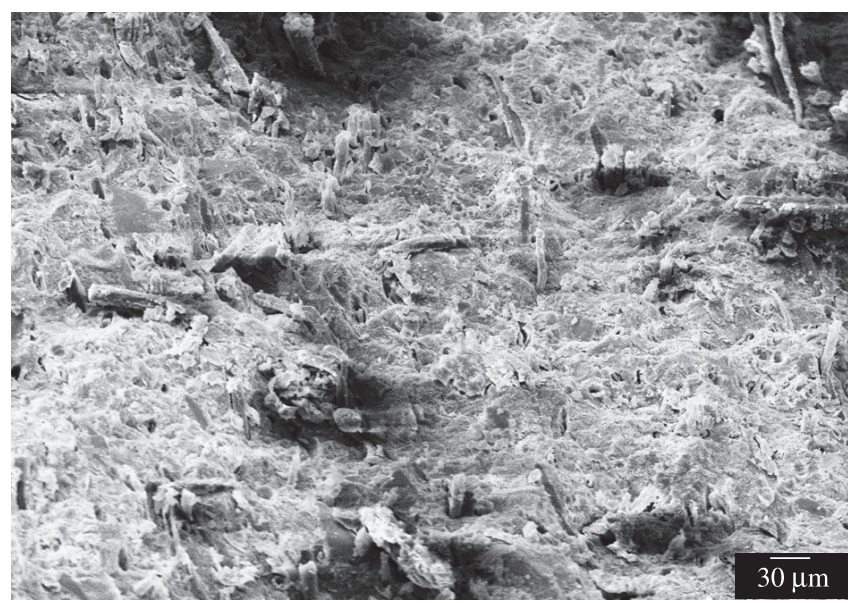

(c)

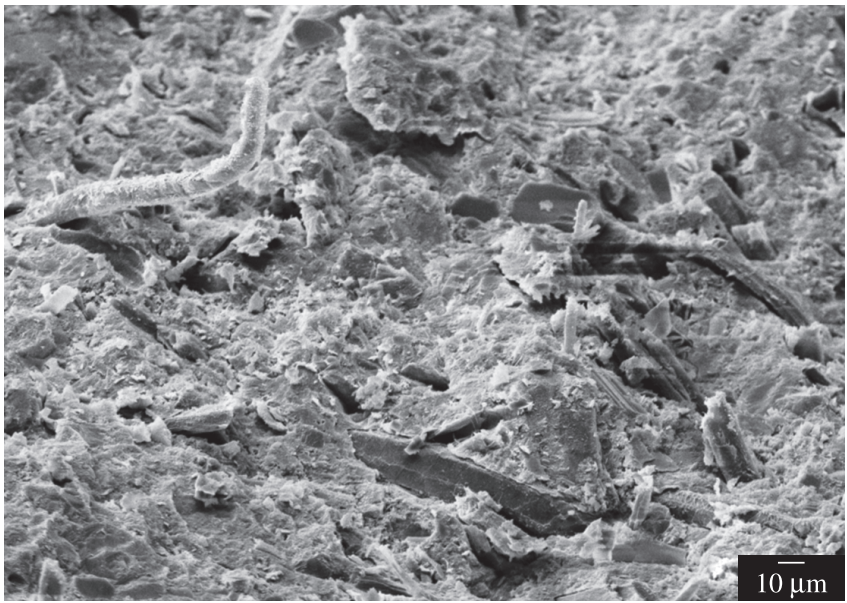

(b)

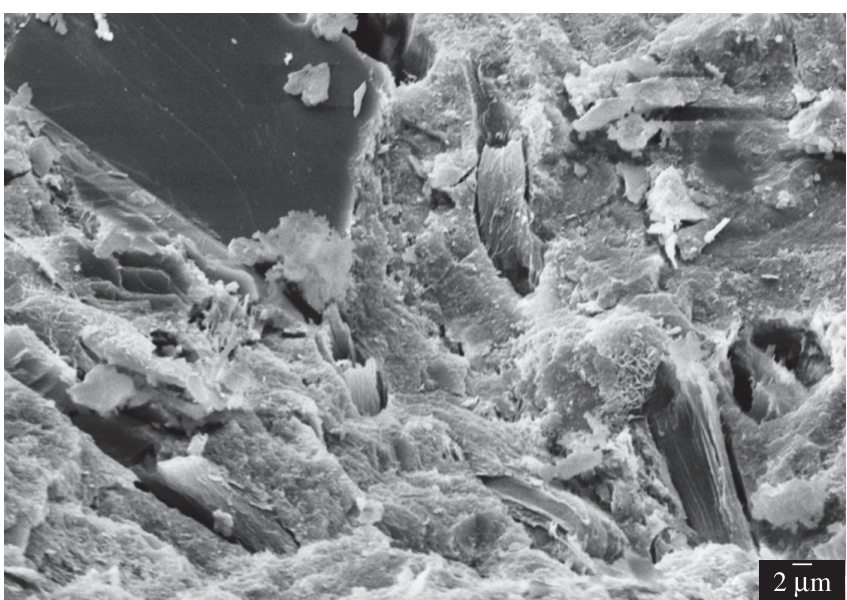

(d)

Figure 7. SEM of fracture surface of composites reinforced with: a) and b) sisal organosolv pulp after 100 soak/dry cycles; c) and d) sisal kraft after fast carbonation followed by 100 soak/dry cycles.

Composites reinforced with only sisal kraft pulp accomplished greater MOR and LOP than composites with hybrid reinforcement (kraft pulp + PP). This behaviour can be attributed to the better adhesion and packing between the cement matrix and cellulose fibres. Unaged composites with organosolv pulp did not present significant differences of MOR and LOP to those ones reinforced with organosolv + PP fibres.

Toughness is often correlated to the length of reinforcing fibre especially in the case of short fibre with length below the critical length. As the stress is transferred from the matrix to the fibre, debonding can take place at the interface and the fibre may be pulled out through the matrix, generating considerable frictional energy losses, which contribute to toughness ${ }^{3}$. At 28 days of cure, the refined kraft pulp provided higher values of toughness and also higher values of MOR than organosolv pulp. Organosolv fibres seem to be weaker than kraft fibres as the pull-out of the organosolv fibres was decreased. Composites reinforced with only organosolv pulped sisal also provided lower toughness than composites reinforced with unrefined kraft pulp according to previous work $^{29}$. Young ${ }^{37}$ suggested that, in general, the strength properties of organosolv pulps are inferior to those of corresponding kraft pulps, what may be related with the great amount of polyoses solubilized $^{38}$. There may be significant contribution to the decay of the reinforcement capacity with the consequent fragile behaviour of the composite.

After ageing, since the cellulose fibres are more adhered to the matrix, the fracture prevails (Figure 7) over the pull out inasmuch as the toughness decreases for samples with only sisal pulps.

Figure 8 presents the stress-strain curves of the composites according to the use of sisal organosolv and kraft pulp for samples without and with polypropylene respectively. The area below the stress-strain curves is related to the absorbed energy by the composites.

Toughness was greatly improved with the addition of PP fibres. The length of the PP fibres (6 mm), higher than sisal pulp fibres, and its intrinsic properties (tensile strength $=300 \mathrm{MPa}$ and modulus of elasticity $=3.3 \mathrm{GPa}$ ), which do not adhere very well to the matrix in the initial ages, contribute to the enhancement of the composite toughness. The improvement of toughness with the addition of PP fibres is also related with the absence of fibrillation, favouring poor anchoring to the matrix and considerable incidence of pulled out fibres (Figures 9a and 9b).

The 100 ageing cycles decreased the toughness of both noncarbonated and fast carbonated composites with kraft pulp + PP fibres. Accelerated carbonation seems to be effective in the maintenance of the toughness of the composites with sisal organosolv pulp combined with PP fibres after ageing. 


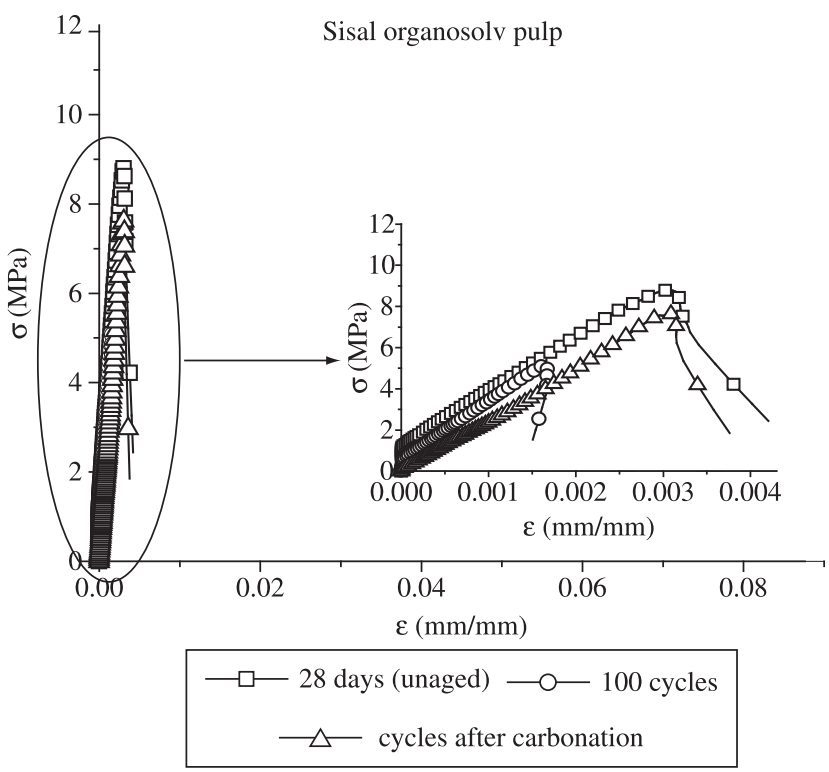

(a)

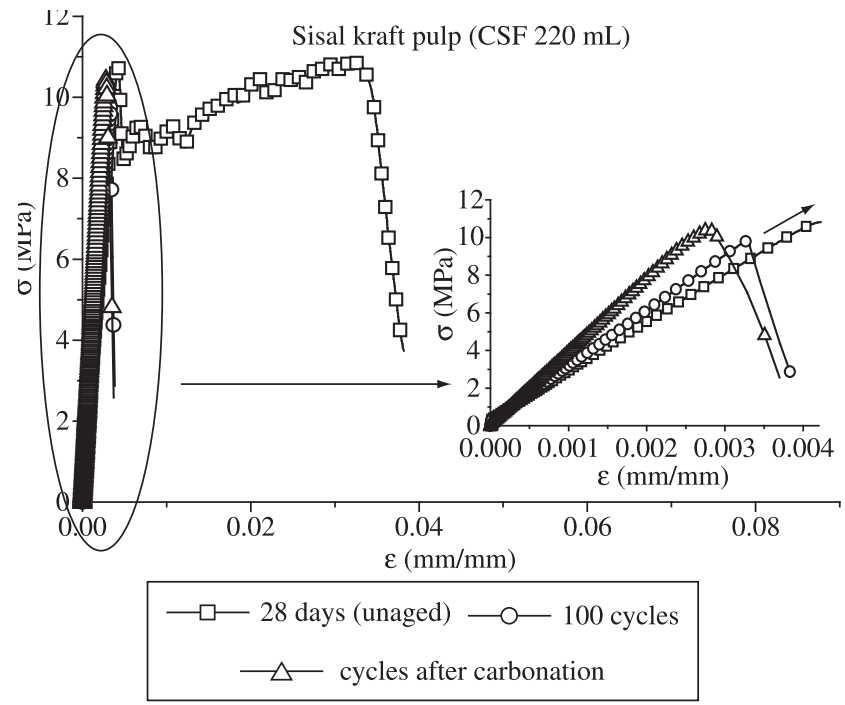

(c)

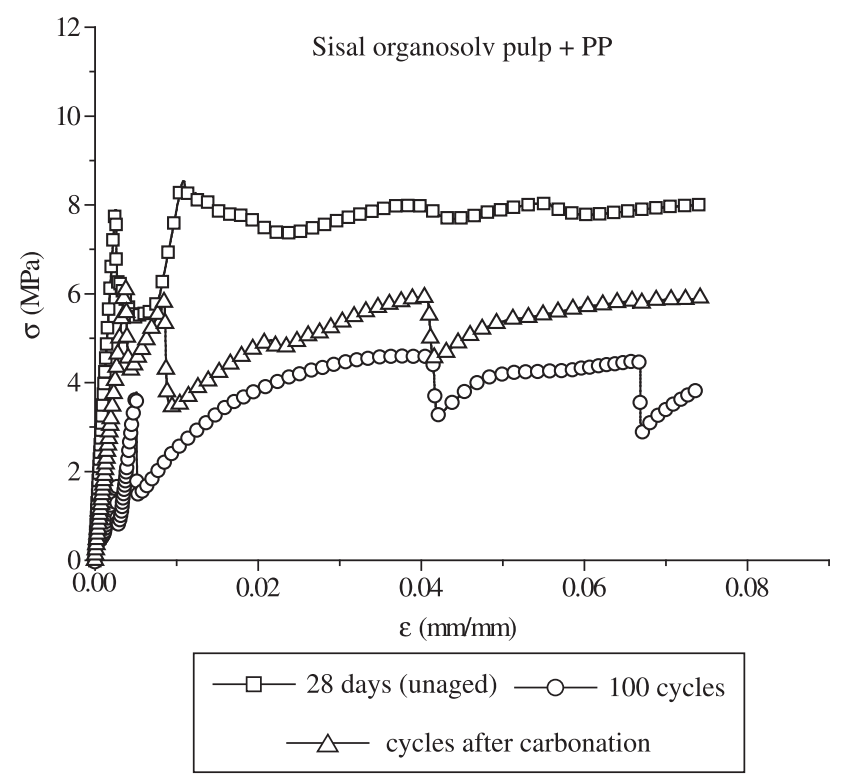

(b)

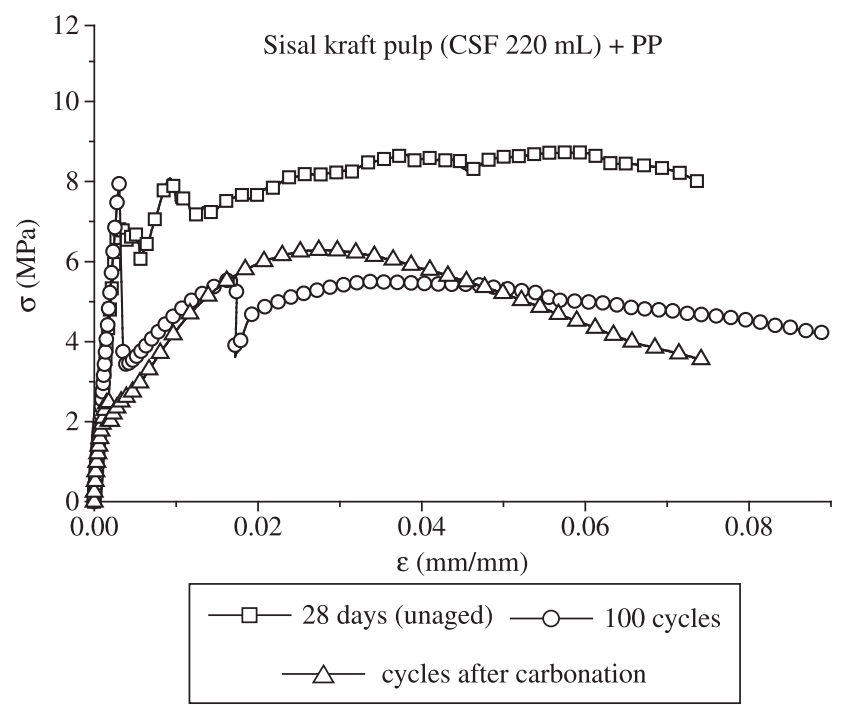

(d)

Figure 8. Stress-strain curves for composites with different reinforcing fibres at 28 days and after 100 cycles with/without fast carbonation: a) sisal organosolv pulp; b) sisal organosolv pulp with polypropylene fibres; c) sisal kraft pulp and d) sisal kraft pulp with polypropylene fibres.

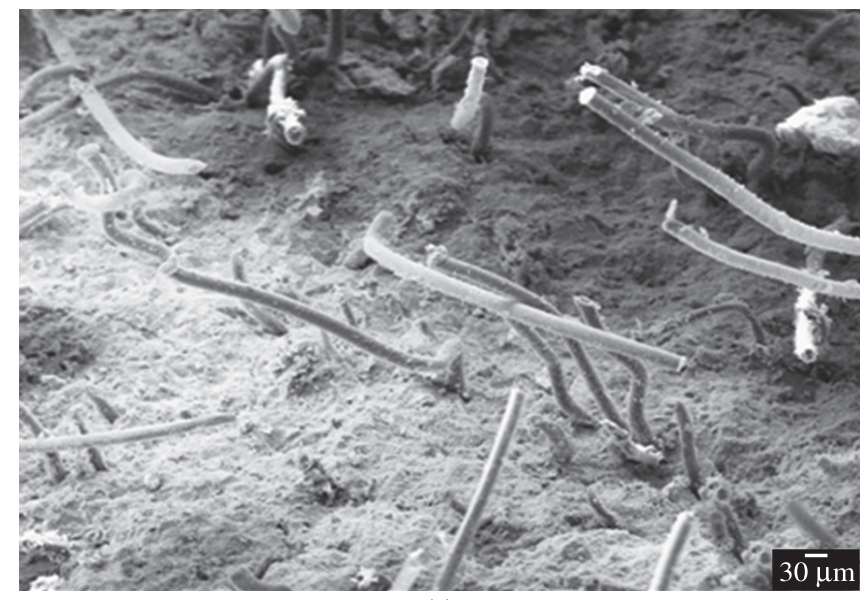

(a)

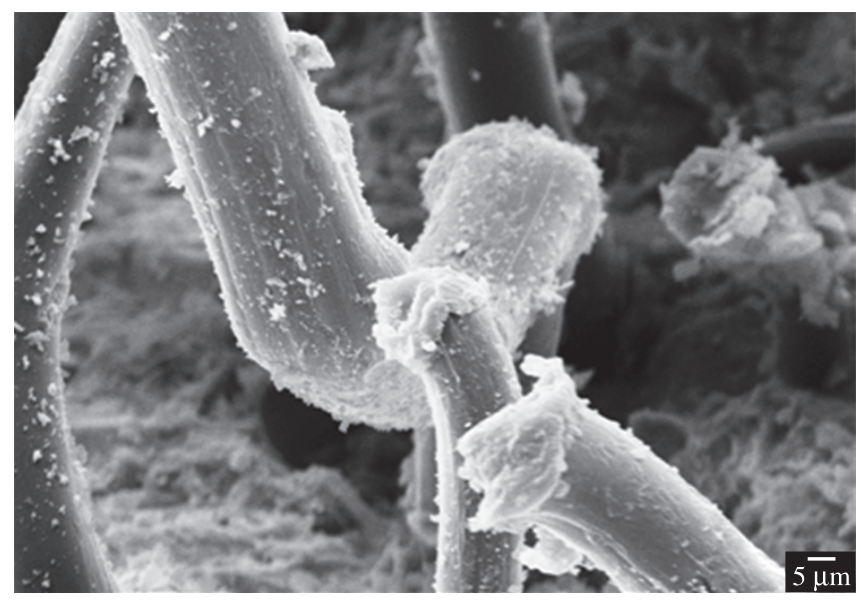

(b)

Figure 9. SEM of fracture surface of composites after 100 soak/dry cycles: a) and b) sisal organosolv pulp + PP fibres. 


\section{Conclusions}

Studies concerning pulping time showed that 2 hours reaction has furnished a good result for delignification and 3 hours reaction was considered more than necessary. Sisal organosolv pulp (unrefined) produced from residues of cordage industry presented smaller and thicker individual fibres than unrefined sisal kraft pulp. These properties had a good influence in physical properties of the composites, since sisal organosolv pulp composites presented lower water absorption and apparent voids volume than composites reinforced with sisal kraft pulp.

In general the composites reinforced with refined kraft pulp have presented higher values of MOR, LOP and toughness. However, the performance of the sisal organosolv reinforced composites can be improved, once the pulping process is not well adapted for the production of this kind of material, differently of the fibre-cement with kraft pulp, which has been extensively studied and developed as reinforcement in cement based matrix.

Sisal organosolv pulp composites after 100 ageing cycles (without fast carbonation) presented lower water absorption and apparent voids volume than composites reinforced with sisal organosolv $+\mathrm{PP}$ fibres. Also, the density of the polypropylene (PP) fibres and the poor packing of the particles with this long fibres provided lower density to the respective composites. Accelerated carbonation promotes densification of the composites and has maintained the resistance of the composites reinforced with refined sisal kraft pulp and of the composites reinforced with sisal organosolv + PP fibres.

The highest toughness was found with the addition of polypropylene fibres in the mixture. Polypropylene fibres are poorly adhered to the cement matrix, favouring insufficient anchorage and considerable incidence of pull out.

This work is part of a more comprehensive project dedicated to the development of asbestos free formulations applied to fibrecement products to meet the needs of emerging countries. The tailoring of these non-conventional composites includes not only the optimization of the cellulose pulp from available raw materials but also the selection of adequate formulations and processes in the fibre-cement production. The obtained results bring encouragement to the continuation of the ongoing research with the compromise between physical and mechanical performance of the composite and its cost of production.

\section{Acknowledgments}

Financial support for this research project and scholarships to the authors were provided by Financiadora de Estudos e Projetos (Finep), Conselho Nacional de Desenvolvimento Científico e Tecnológico (CNPq), Coordenação de Aperfeiçoamento de Pessoal de Nível Superior (Capes) and Fundação de Amparo à Pesquisa do Estado de São Paulo (Fapesp process no 2005/59072-4), in Brazil. Sisal by-product was provided by APAEB - Valente, polypropylene and cement rawmaterial were kindly furnished by Infibra Ltda.

\section{References}

1. Bentur A. Fiber-reinforced cementitious materials. In: Skalny JP. (editor) Materials science of concrete. Waterville: The American Ceramic Society; 1989. p. 223-84.

2. Guimarães SS. Vegetable fiber-cement composites. In: Sobral HS. (editor). Proceedings of the Second International RILEM Symposium on Vegetable Plants and their fibres as Building Materials. London: Chapman \& Hall; 1990. p. 98-107.

3. Savastano Jr. H, Warden PG and Coutts RSP. Potential of alternative fibrecements as building materials for developing areas. Cement \& Concrete Composites. 2003; 25(6):585-592.
4. Dahlmann G and Schroeter MC. The Organocell process - pulping with the environment in mind. Tappi Journal. 1990; 73(4):237-240.

5. Nimz HH, Granzow $\mathrm{C}$ and Berg A. Acetosolv Pulping. Holz als Roh und Werkstoff. 1986; 44(9):362.

6. Wang IC, Kuo ML and Ku YC. Alcohol pulping of plantation taiwania and eucalyptus, scanning electron microscope observations. Bulletin of Taiwan Forest Research Institute 1993; 8(3):177-185.

7. Oliet M, García J, Rodríguez F and Gilarranz MA. Comparative study between ethanol and methanol as delignifying agents. Chemical Engineering Journal 2002; 87(2):157-162.

8. Aziz S and McDonough T. Solvent Pulping - Promise and Programs. Tappi Journal. 1988; 71(2):251-256.

9. Pereira H, Oliveira MF and Miranda I. Kinetics of Ethanol Water Pulping and Pulp properties of Eucalyptus globulus lab. Appita 1986; 39(6):455-458.

10. Perez DS. Cinetic study of acetone-water delignification of Eucalyptus urograndis. [Master Dissertation]. São Carlos: Instituto de Química de São Carlos, Universidade de São Paulo; 1996. 115 p. (in Portuguese).

11. Sarkanen KV. Chemistry of solvent pulping. Tappi Journal. 1990; 73(10):215-219.

12. McDonough TJ. The Chemistry of Organosolv Delignification. Tappi Journal. 1993; 76(8):186-193.

13. Aziz S and Goyal GC. Kinetics of delignification from mechanistic and process control point of view in solvent pulping processes. In Pulping Conference Proceedings; 1993; Atlanta, GA. p. 917-920.

14. Kleinert TN. Ethanol-water delignification of wood - rate constants and activation energy. Tappi Journal. 1975; 58(8):170-171.

15. Gallagher DK, Hergert HL, Cronlund M and Landucci LL. Mechanism of delignification in an autocatalyzed solvolysis of aspen. In International Symposium on Wood and Pulping Chemistry Proceedings; 1989; Tappi Press; Raleigh, NC. p. 709-718.

16. Paszner L and Behera NC. Topochemistry of softwood delignification by alkali earth metal salt catalysed organosolv pulping. Holzforschung. 1989; 43(3):159-168.

17. Bendzala J and Kokta BV. Optimization and fundamentals of high-yeld pulping with etanol. Wood Science Technology. 1995; 29(6):467-479.

18. Mohr BJ, Biernacki JJ and Kurtis KE. Microstructural and chemical effects of wet/dry cycling on pulp fiber-cement composites. Cement \& Concrete Research. 2006; 36(7):1240-1251.

19. Instituto de Pesquisas Tecnológicas do Estado de São Paulo S.A. Fibre/ agro-industrial by products bearing walls. São Paulo: AMPC/DCC/IPT; 1989. Report n. ${ }^{\circ}$ 27.937. (In Portuguese).

20. Chand N, Tiwary RK and Rohatgi PK. Bibliography: resource structure properties of natural cellulosic fibres - an annotated bibliography. Journal of Materials Science. 1988; 23(2): 381-387.

21. Coutts RSP and Ridikas V. Refined wood fibre-cement products. Appita. 1982; 35(5):395-400.

22. Savastano Jr. H, Warden PG and Coutts RSP. Brazilian waste fibres as reinforcement for cement-based composites. Cement \& Concrete Composites. 2000; 22(5):379-384.

23. Associação Brasileira de Normas Técnicas - ABNT. NBR 11578. Compound Portland Cement, Test methodologies and aggregates. Rio de Janeiro; 1991. (In Portuguese).

24. TAPPI T222 om-88. Acid-insoluble lignin in wood and pulp. Atlanta, GA, USA: Technical Association of the Pulp and Paper Industry; 1988.

25. Goldschimid O. Ultraviolet spectra. In: Sarkanen KV and Ludwig CH. Lignins: occurrence, formation, structure and reactions. New York: John Wiley Interprice; 1971. p. 241-298.

26. Browning BL. Methods of wood chemistry. New York: Interscience Publishers; 1967. p. 395.

27. Pasquini D, Pimenta MTB, Ferreira LH and Curvelo AAS. Sugar cane bagasse pulping using supercritical $\mathrm{CO}_{2}$ associated with co-solvent 1-butanol/water. The Journal of Supercritical Fluids. 2005; 34(2): 125-131. 
28. Bezerra EM, Savastano Jr. H, John VM and Agopyan V. Mineral additions and their influence on fiber cement behavior. In: Proceedings of the Ninth International Conference Inorganic-Bonded Composite Materials; 2004. Moscow: University of Idaho; 2004. 12 p. (CD-Rom).

29. Tonoli GHD, Joaquim AP, Arsene MA, Bilba K and Savastano Jr. H. Refinement of Sisal Pulp: Effect on the Mechanical Performance and Durability of Cement Based Composites. Materials and Manufacturing Process. 2007; 22(2):149-156.

30. Agopyan V, Savastano Jr. H, John VM and Cincotto MA. Developments on vegetable fibre-cement based materials in São Paulo, Brazil: an overview. Cement \& Concrete Composites. 2005; 27(5):527-536.

31. European Standard. EN 494. Fibre-cement profiled sheets and fittings for roofing - Products specification and test methods. [S.1.]; 1994.

32. American Society for Testing and Materials. ASTM C 948. Test Method for Dry and Wet Bulk Density, Water Absorption, and Apparent Porosity of Thin Sections of Glass-Fiber Reinforced Concrete. West Conshohocken, PA, USA; 1981.
33. Savastano Jr. H, Warden PG and Coutts RSP. Microstructure and mechanical properties of waste fibre-cement composites. Cement \& Concrete Composites. 2005; 27(5):583-592.

34. Hon DNS. Pragmatic approaches to utilization of natural polymers: challenges and opportunities. In: Natural polymers and agrofibers based composites. Frollini E, Leão AL, Mattoso LHC. (Eds.). São Carlos: USP-IQSC, Embrapa Instrumentação Agropecuária. Botucatu: UNESP; 2000. p. 1-14.

35. Saarela J, Törmäanen M and Myllylä R. Measuring pulp consistency and fines content with a streak camera. Measurement Science and Technology. 2003; 14(10):1801-1806. Institute of Physics Publishing.

36. Muurinen E. Organosolv pulping: A review and distillation study related to peroxyacid pulping. [Dissertation]. Oulu: University of Oulu; 2000. $314 \mathrm{p}$.

37. Young RA. Comparison of the properties of chemical cellulose pulps. Cellulose. 1994; 1(2):107-130.

38. Paszner L and Behera NC. Beating behavior and sheet strength development of coniferous organosolv fibers. Holzforschung. 1985; 39(1):51-61. 